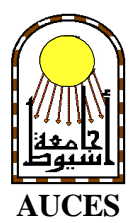

\title{
INCIDENCE OF CERTAIN ARTHROPOD PESTS AND PREDATORS INHABITING COWPEA, WITH SPECIAL REFERENCE TO THE VARIETAL RESISTANCE OF SELECTED CULTIVARS TO BEMISIA TABACI (GEN.) AND TETRANYCHUS URTICAE KOCH.
}

\author{
Mohamed Abdel-Rahman Mohamed Amro \\ Plant protection Research Institute, Agricultural Research Center, Dokki, Egypt
}

\begin{abstract}
:
Incidence and faunistic composition of arthropod pests and their associated predators in cowpea plantations have been determined during 2000 and 2001 growing seasons in Assiut Governorate. Fifteen phytophagous species and five arthropod predators in addition to unidentified true spiders were recorded by using sweep net method. Results indicated that the dominance percentages of arthropod pests was higher than those of predators. The most dominant pest species were the piercing sucking pests Empoasca spp.; Nezara viridula, Creontiades pallidus and the lycaenid Lambides boeticus. However, the most dominant predators were Coccinella undecimpunctata; Orius spp. and Scymmus interruptus. Also results, exhibited distinct compatability between the abundance of the above mentioned pests and their associated predators. These results must be use to enable these biological control agents in suppressing cowpea pests and regulate their numbers. Regarding to the relative susceptibility of the tested cowpea cultivars to the whitefly Bemisia tabaci and the two spotted spider mite Tetranychus urticae the cowpea cultivar Kaha 1 only showed some sort of resistance against the two pests. It appeared as low resistant (LR) and moderately resistant (MR) cultivar against these two pests, respectively. Leaf morphological characters and/or sap nutrients of this cultivar may be the main factors responsible for the existence of these resistance degrees. Therefore, plant breeders must be study characters of this cultivar in more details and transfere the desirable one's into the other new produced cowpea cultivars.
\end{abstract}

\section{INTRODUCTION:}

Cowpeas (blackeye peas, or simply beans in many parts of Africa), Vigna unguiculata, L (Walp) are widely grown in the tropics and subtropics for human as well as for animal food. They are eaten as green seeds, green pods and dry grains. Tender leaves are used as a vegetable (Kayumbo, 1978). In Egypt, cowpeas has been subjected to attack by several pests (Harakly, 1972 and El-Kifl et al., 1974). The whitefly (WF) Bemisia tabaci and the two spotted spider mite (TSSM) Tetranychus urticae have been reported as severe cowpea pests in Southern Upper Egypt (Abdel-Alim, 1994 and Abou El-Saad, 1998). Nowdays, control strategies must be developed to control cowpea 
pests without using insecticides. Resistant plants appears to be one of the most promising alternatives to the use of chemicals for cowpea pests control as reported by Nosser, (1996); Amro, (1999); Mohamed et al., (2000) and Abdel-Galil et al., (2001). Therefore, the present study was initiated to recover the incidence of the cowpea pests and their associated predators and determine their faunistic composition. Also, to determine the relative susceptibility of certain cowpea cultivars to $B$. tabaci and $T$. urticae under Southern Egypt circumstances.

\section{MATERIALS AND METHODS:}

The present study was carried out in the Experimental Farm of the Faculty of Agriculture, Assiut University, during the two successive cowpea growing seasons 2000 and 2001. An area of about 1/8 feddan was cultivated with 5 cowpea cultivars which obtained from Faculty of Agriculture, Assiut University and Horticulture Institute, Agricultural Research Center. The experiment was carried out in completely randomized block design, with three replicates (1/400 fed.) per each cultivar. Regular conventional practices were normally performed and insecticides were prevented.

1-Faunistic composition of arthropod pests and predators inhabiting cowpea plantations:

Sweep net method have been used to study the faunistic composition of arthropod pests and their associated predators inhabiting cowpea plantations. Four samples of 50 double sweeps $/ 100 \mathrm{~m}^{2}$ were randomly taken weekly 60 days after plantations till harvesting. Each collected sample was emptied into a labelled collecting muslin bag and transferred into the laboratory. Specimens were killed by chloroform and examined under steriomicroscope. Number of individual and species of each sample was recorded. Identification of collected arthropods was made by the specialists of Insect Classification Department, Plant Protection Research Institute, Agricultural Research Center.

\section{2-Dominance and abundance} percentages of the recovered species:

By using the same above mentioned samples, dominance and abundance percentages of arthropod pests and predators inhabiting cowpea plantations were determined by the formula(s) of Facylate (1971) as follows:

$$
1-D=(t / T) \times 100
$$

where:

$D=$ Dominance percentage.

$t=$ Total number of each species during collecting period.

$T=$ Total number of all species collected during the collecting period.

$$
2-A=(n / N) \times 100
$$

where,

A= Abundance percentage

$\mathrm{n}=$ Total number of samples in which each species appeared.

$\mathrm{N}=$ Total number of samples taken all over the season.

3-Susceptibility of cowpea cultivars to the whitefly Bemisia tabaci and the two spotted spider mite Tetranychus urticae:

The whitefly and the spider mite populations were monitored weekly during July, August and September in the two cowpea successive growing seasons. Samples of 5 trifoliate leaves were picked up at random from each abovementioned experimental unit. Numbers of the whitefly (nymphs) and the spider mite (mobile stages) which refere to the seasonal fluctuations of these pests were calculated. The classification of the susceptibility degree of each cowpea cultivar 
were dependent on the general mean number $(\bar{X})$ of the (WF) and/or the (TSSM) and the standard deviation (SD) as reported by Chiang and Talekar (1980). The cultivars that had mean numbers more than $\bar{X}+2 S D$, considered highly susceptible (HS); between $\bar{X}$ and $\bar{X}+2 S D$, susceptible (S); between $\bar{X}$ and $\bar{X}-1 S D$, low resistant (LR); between $\bar{X}$-1SD and $\bar{X}-2 S D$, moderately resistant (MR) and less than $\bar{X}-2 S D$, were considered highly resistant (HR).

Data obtained were statistically analyzed by using F-test. The means were compared according to Duncan's multiple range test (Duncan, 1955).

\section{RESULTS AND DISCUSSION:}

1-Faunistic composition of arthropod pests and predators inhabiting cowpea plantations:

A partial taxonomic list of arthropod pests and predators recovered from cowpea plantations is reported in Table (1). Arthropod pests were represented by 15 species belonging to 9 families and 4 orders. However, arthropod predators were represented by 5 species belonging to 4 families and 4 orders. Unidentified true spiders were also countered. In a similar study, El-Sayed (1993) recorded 16 insect pest species and 8 arthropod predators in addition to 8 parasitoid species in association with cowpea plantations in Minufiya Governorate.

\section{2-Dominance and abundance percentages of the recovered species:}

Data presented in Table (2) indicate the dominance and abundance percentages of arthropod pests and predators inhabiting cowpea plantations. The dominance percentages of arthropod pests were so high and represented by 90.53 and $96.86 \%$ during 2000 and 2001 growing seasons, respectively. However, the dominance percentages of the associated predators were low and represented by 9.47 and $3.14 \%$ during the same period. The leafhopper Empoasca spp., revealed the highest dominance percentage during the period of study. It followed by the Heteropteran sucking pests Nezara viridula and Creontiades pallidus and then by the Lycaenid Lambides boeticus. The rest of the herbivorous species were represented in low dominance percentages. In order to the predaceous species the lady bird beetle Coccinella undecimpunctata revealed the highest dominance percentage. It followed by the Heteropteran predator Orius spp. and the Coccinellid Scymnus interruptus. The true spiders also, were represented in high dominance percentages. Concerning the abundance percentages, the above mentioned phytophagous and predaceous species were exhibited the highest abundance percentages. This synchronyzation and/or agreement between the incidence of the main cowpea serious pests and their associated predators may be increase the ability of these biological control agents in suppressing the populations of insect pests and regulate their numbers. In this respect, very few numbers of biological control agents that have potential importance in cowpea pests suppression have been reported by few workers such as Hammad, (1978); Saharia, (1980) and Daoust et al., (1985). Though, the current investigation may be consider as a view on the relationship between the herbivorous cowpea insects and their associated predators which may be maintain their population densities so low that their effect on plant dynamics would be small. 
Table (1) : A taxonomic list of collected arthropod pests and predators recovered by sweep net from cowpea plantations, Assiut 2000 and 2001.

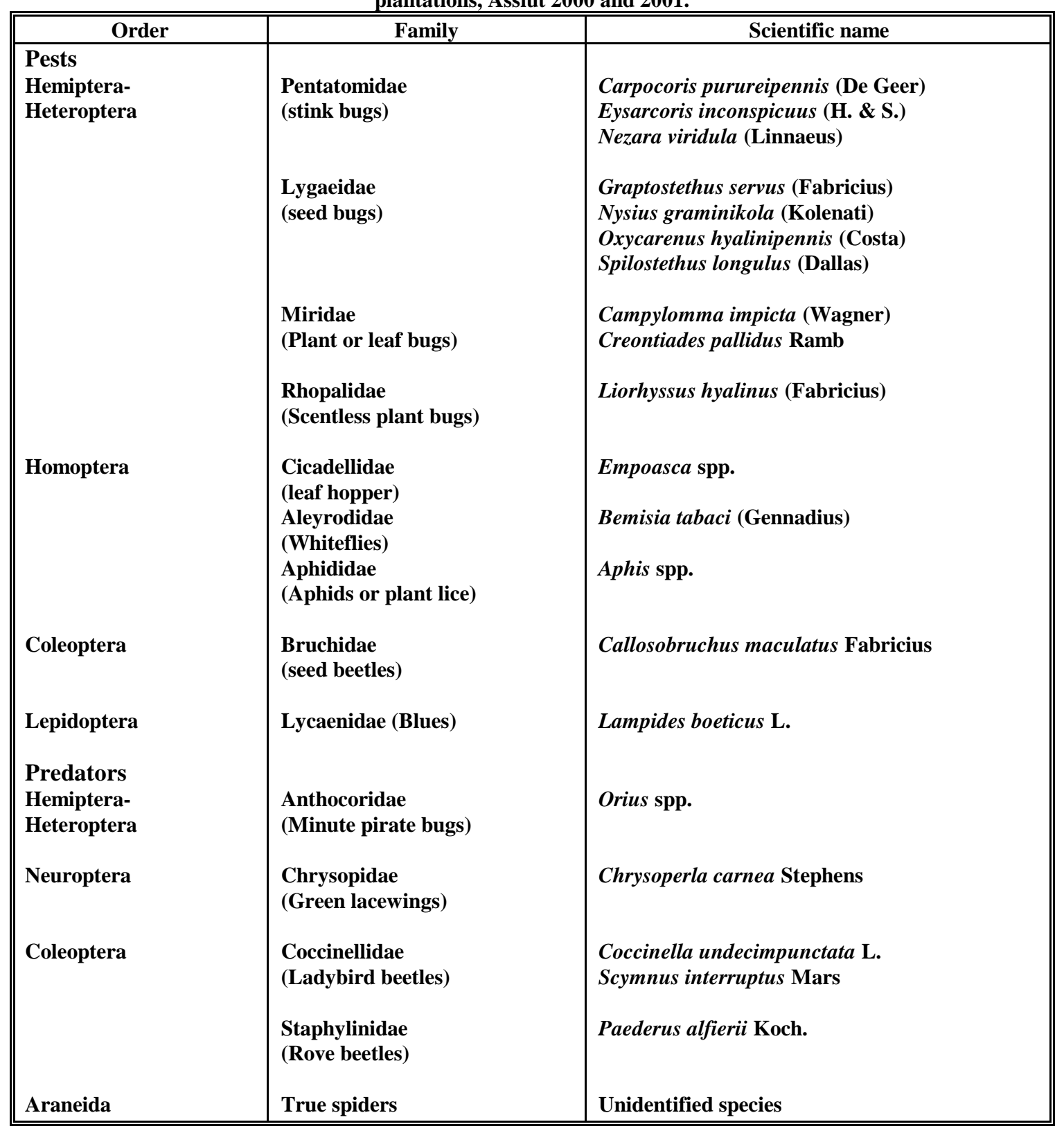


Table (2):Dominance and abundance percentages of the recovered arthropod species from cowpea plantations, Assiut 2000 and 2001.

\begin{tabular}{|c|c|c|c|c|}
\hline \multirow{2}{*}{ Recovered species } & \multicolumn{2}{|c|}{ Dominance \% } & \multicolumn{2}{|c|}{ Abundance \% } \\
\hline & 2000 & 2001 & 2000 & 2001 \\
\hline Pests & 90.53 & 96.86 & & \\
\hline Carpocoris purureipennis (De Feer) & 0.44 & 0.42 & 42.85 & 42.85 \\
\hline Eysarcoris incospicuus (H. \& S.) & 0.12 & 0.00 & 21.42 & 0.00 \\
\hline Nezara viridula (Linnaeus) & 2.45 & 4.20 & 78.57 & 100.00 \\
\hline Nysius graminikola (Kolenati) & 0.04 & 0.08 & 7.14 & 14.28 \\
\hline Oxycarenus hyalinipennis (Costa) & 0.08 & 0.08 & 14.28 & 14.28 \\
\hline Spilostethus longulus (Dallas) & 0.04 & 0.00 & 7.14 & 0.00 \\
\hline Campylomma impicta (Wagner) & 0.48 & 0.00 & 7.14 & 0.00 \\
\hline Creontiades pallidus Ramb & 2.66 & 1.33 & 85.71 & 71.42 \\
\hline Liorhyssus hyalinus (Fabricius) & 0.00 & 0.08 & 0.00 & 14.28 \\
\hline Empoasca spp. & 89.58 & 92.81 & 100.00 & 100.00 \\
\hline Aphis spp. & 1.45 & 0.08 & 35.71 & 14.28 \\
\hline Callosobruchus maculatus Fabricius & 0.08 & 0.00 & 7.14 & 0.00 \\
\hline Lampides boeticus $\mathbf{L}$. & 2.58 & 0.92 & 64.28 & 64.28 \\
\hline Predators & 9.47 & 3.14 & & \\
\hline Orius spp. & 27.31 & 20.51 & 78.57 & 42.85 \\
\hline Chrysoperla carnea Stephens & 4.62 & 2.56 & 50.00 & 14.28 \\
\hline Coccinella undecimpunctata $\mathrm{L}$. & 43.08 & 14.10 & 100.00 & 55.55 \\
\hline Scymnus interruptus Mars & 15.38 & 21.80 & 64.28 & 85.71 \\
\hline Paederus alfierii Koch. & 1.15 & 2.57 & 14.28 & 14.28 \\
\hline True spiders & 8.46 & 38.46 & 85.71 & 100.00 \\
\hline
\end{tabular}

3-Susceptibility of cowpea cultivars to the whitefly Bemisia tabaci and the two spotted spider mite Tetranychus urticae:

Data presented in Table (3) exhibit the average numbers and the susceptibility degrees of cowpea cultivars to the (WF) and the (TSSM) collected during 2000 and 2001 growing seasons.

\section{a-The whitefly $B$. tabaci:}

Statistical analysis of the data revealed highly significant differences between the mean numbers of this pest on the tested cultivars $(F=$ 39.95>0.01). The cowpea cultivars, Monarch blackeye; Dokki 331 and TVu21 improved were suffer from highly infestations with an average of 23.50, 21.17 and 20.17 nymphs/15 trifoliate cowpea leaves, respectively. However, Kaha 1 and Kafr El-Seikh 1 were infested by quitely low numbers with an average of 14 and 12.17 nymphs/15 leaves, respectively. In respect to the susceptibility degrees, the first three cultivars appeared as susceptible (S) cultivars, whereas they harboured high numbers of this pest. The other two cultivars which harboured quitely low numbers showed some sort of resistance and appeared as low resistant (LR) and moderately resistant (MR) cultivars, respectively. Therefore it is important to point out herein that the insect mean numbers must be refere to and/or agree with the resistant degree of each cultivar. These differences in infestation may be due to leaf characters of each cowpea cultivar. Although the resistance mechanism in the tested cowpea cultivars is not clear, antixenosis "nonpreference" phenomenon probably responsible. This phenomenon may be dependent on the hooked trichomes density which can deter the adult ovipositer from reaching to the leaf surface. About this phenomenon, Pillemer and Tingey (1976) reported that hooked trichomes can capture the leafhopper nymphs and may be consider as a resistant mechanism. 
b-The two spotted spider mite Tetranychus urticae:

In respect to the mean numbers and the degree of infestation of the (TSSM), results showed the existence of highly significant differences between the tested cultivars ( $F=$ 75.59>0.01). In this respect, the lowest value was recorded on the cowpea cultivar Kaha 1 with an average of 3.17 individuals/15 trifoliate cowpea leaves. The rest cultivars recorded high infestation values. According to the measurements of the susceptibility degrees, the obtained results indicated that all of the tested cultivars appeared as susceptible ( $S$ ) cultivars, except of Kaha 1 which appeared as moderately resistant (MR) cultivar. These variations in cultivar's resistance degrees may be due to the presence of antixenosis (nonpreference) and/or antibiosis characteristics distinguishable the last cultivar than the others. The obtained results can be documented by those reported by Metwally et al. (1991) who proved that, life cycle, generation and pre-oviposition period of T. urticae were prolonged when it reared on the cowpea tolerant cultivars, while its longevity and oviposition period were longer and its fecundity were higher when it reared on the susceptible cultivars.

Table (3): Average numbers ${ }^{(a)}$ and susceptibility degrees of cowpea cultivars to Bemisia tabaci and Tetranychus urticae, Assiut 2000 and 2001.

\begin{tabular}{|c|c|c|c|c|c|c|c|c|}
\hline \multirow[b]{2}{*}{$\begin{array}{c}\text { Cowpea } \\
\text { cultivar (s) }\end{array}$} & \multicolumn{3}{|c|}{ B. tabaci } & \multirow{2}{*}{ 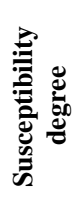 } & \multicolumn{3}{|c|}{ T. urticae } & \multirow{2}{*}{ 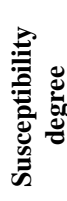 } \\
\hline & 2000 & 2001 & Mean \pm SD & & 2000 & 2001 & Mean \pm SD & \\
\hline TVu 21 improved & $18.00^{\mathrm{a}}$ & $22.33^{\mathrm{a}}$ & $20.17 \pm 3.06^{b}$ & $\mathbf{S}$ & $9.33^{b}$ & $10.00^{b}$ & $9.67 \pm 1.21^{b}$ & $\mathbf{S}$ \\
\hline Monarch blackeye & $20.33^{\mathrm{a}}$ & $26.67^{\mathrm{a}}$ & $23.50 \pm 4.23^{\mathrm{a}}$ & $\mathbf{S}$ & $9.67^{b}$ & $9.33^{b}$ & $9.50 \pm 1.05^{b}$ & $\mathbf{S}$ \\
\hline Dokki 331 & $23.00^{\mathrm{a}}$ & $19.33^{b}$ & $21.17 \pm 2.75^{b}$ & $\mathbf{S}$ & $9.33^{b}$ & 11.33ab & $10.33 \pm 2.07^{b}$ & $\mathbf{S}$ \\
\hline Kaha 1 & $9.67^{b}$ & $18.33^{b}$ & $14.00 \pm 4.89^{\mathrm{c}}$ & LR & $3.67^{\mathrm{c}}$ & $2.67^{c}$ & $3.17 \pm 0.98^{c}$ & MR \\
\hline Kafr El-Seikh 1 & $11.00^{b}$ & $13.33^{c}$ & $12.17 \pm 1.72^{c}$ & MR & $15.67^{\mathrm{a}}$ & $12.67^{\mathrm{a}}$ & $14.17 \pm 1.83^{\mathrm{a}}$ & $\mathbf{S}$ \\
\hline Mean & 16.40 & 19.99 & 18.20 & & 9.53 & 9.20 & 9.37 & \\
\hline F-value & $24.46^{* * *}$ & $37.75^{* * *}$ & $39.95^{* *}$ & & $49.18^{* * *}$ & $31.35^{* *}$ & $75.59 * *$ & \\
\hline
\end{tabular}

(a) Based on 5 trifoliate cowpea leaves/plot.

F value: $* *$ = Highly significant at 0.01 level of probability.

Means followed by the same letter in each column are not significantly different at 0.05 level of probability by Duncan's multiple range test.

S= Susceptible LR= Low Resistant $\quad$ MR= Moderately Resistant.

Generally, it can be concluded that morphological leaf characters such as hooked trichomes density and the sap nutrients may be responsible as resistant mechanisms against the (WF) B. tabaci and the (TSSM) T. urticae. These phenomena must be studied in more details and transfere with another desirable resistant phenomena by plant breeders into the locally new produced cowpea cultivars especially which exhibit some sort of resistance to these pests. 


\section{REFERENCES :}

Abdel-Alim, A.A. 1994. Ecological studies on certain insects infesting cowpea plants in Minia region. Minia J. Agric. Res. \& Dev. 16 (2): 261-274.

Abdel-Galil, F.A.; M.A. Morsi; S.H. Mohamed and M.A. Amro. 2001. Control strategy of the lima bean pod borer Etiella zinckenella Treit. infesting cowpea in the new reclaimed areas. Proceedings of the 1st Congress of Integrated Pest Management, Cairo Univ., 1: 25-32.

Abou El-saad, A.K. 1998. Ecological studies on piercing sucking pests infesting cowpea and their control in Assiut Governorate. M.Sc. Thesis, Fac. Agric., Assiut Univ.

Amro, M.A. 1999. Ecobiological studies on certain arthropod pests infesting selected cowpea cultivars and control strategy in arid-ecosystems. Ph.D. Thesis, Fac. Agric., Assiut Univ.

Chiang, H.S. and N.S. Talekar. 1980. Identification of sources of resistance to the bean fly and two other agromyzid flies in soybean and mungbean. J. Econ. Entomol., 73: 197-199.

Daoust, R.A.; D.W. Roberts and B.P. Neves. 1985. Distribution, biology and control of cowpea pests in Latin America. In Cowpea Research, Production and Utilization, ed. Singh, S.R. and K.D. Rachie, 251-266. London, John Wiley.

Duncan, D.B. 1955. Multiple range and multiple F-test. Biometrics, 1: 1-42.

El-Kifl, A.H.; A.E.A. Wahab; M.A. Assem and A.A. Metwally. 1974. List of insects, mites and pests associated with leguminous crops in Egypt. Bull. Soc. ent. Egypte, 58: 297-302.

El-Sayed, A.M. 1993. Insect pests and their associated natural enemies on cowpea (Vigna unguiculata) plants. Zagazig J. Agric. Res., 20 (3): 1175-1183.
Facylate, K.K. 1971. Field studies in soil invertebrate. $2^{\text {nd }}$ ed. Vishia Shkoola Press, Moscow, USSR.

Hammad, S.M. 1978. Pests of grain legumes and their control in Egypt. In: Singh, S.R.; H.F. van Emden and T.A. Taylor (ed.). Pests of grain legumes: Ecology and Control. 135-137. Academic Press Inc. London, New York.

Harakly, F.A. 1972. A list of pests infesting vegetable marrow in Egypt. Agric. Res. Rev. 50 (1): 105.

Kayumbo, H.Y. 1978. Pests of cowpea and their control in Tanzania. In: Singh, S.R.; H.F. van Emden and T.A. Taylor (ed.). Pests of grain legumes: Ecology and Control. 123-126. Academic Press Inc. London, New York.

Metwally, S.A.G.; M.K. Megali and F.S. Faris. 1991. Evaluation of some cowpea cultivars to the infestation of some pests. Proceedings of the Fourth Arab Congress of Plant Protection, Cairo 1-5 Dec. : 1: 403-413.

Mohamed, S.H.; F.A. Abdel-Galil; M.A. Morsi and M.A. Amro. 2000. Susceptibility of cowpea cultivars to natural infestation with the whitefly, Bemisia tabaci Gennadius and the two-spotted spider mite, Tetranychus urticae Koch. Proceedings of the 2nd Scientific Conf. Agric. Sci., Assiut Univ., 601-611.

Nosser, M.A. 1996. Mechanism of resistance in bean and cowpea varieties to certain sucking insects infestation. M.Sc. Thesis, Fac. Agric., Cairo Univ.

Pillemer, E.A. and W.M. Tingey. 1976. Hooked trichomes: A Physical plant barrier to a major agricultural pest. Science, N.Y., 193: 482-484.

Saharia, D. 1980. Natural regulation of population of Aphis craccivora Koch. on 
Ass. Univ. Bull. Environ. Res. Vol. 7 No. 1, March 2004

cowpea. J. Res. Assam Agric. Univ. 1:

171-176.

$-38-$ 


\section{تواجد بعض الآفات من مفصليات الأرجل والمفترسات المصاحبة لها على زراعات

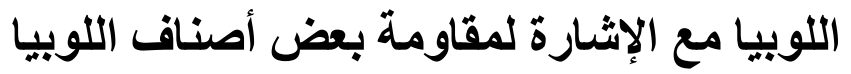

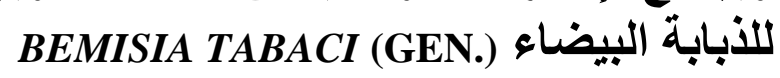 TETRANYCHUS URTICAE KOCH. وأكاروس العنكبوث الأحمر حمه عبد الرحمن عحم عمرو معهد بحوث وقاية النباتات - مركز البحوث الزراعية - الدقى - مصر}

تم حصر الآفات الحثرية من مفصليات الأرجل والمفترسات المصاحبة لها على زراعات اللوبيا ودراسـة تركيبها

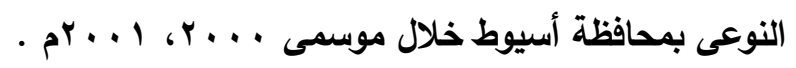
أظهرت النتائج تواجد ه 1 نوعاً من الحشرات آكلة النباتات وصاحبها خمسـة أنواع من المفترسـات الحشرية بالإضافة لبعض العناكب. وقد وجد أن درجة السيادة للآفات كانت عالية جداً مقارنـة بسيادة المفترسـات المصاحبة Nezara viridula تلاها البقة الخضراء Empoasca spp. لهاء وقد كانت أكثر الآفات سيادة هى نطاطات الأوراق ثم بق إسقاط البراعم الزهرية واللوز Creontiades pallidus ثم أبى دقيق البقوليات Lambides boeticus ـ بينما كانت أكثر المفترسات سيادة هو أبى العيد ذو الإحدى عشر نقطة Cocinella undecimpunctata ثم بق الأزهار

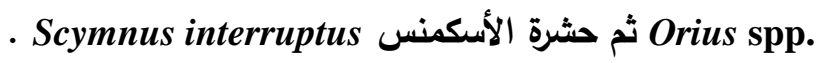
كما أظهرت النتائج أيضاً درجة واضحة من التوافق بين وفرة كل من الآفات الحشرية والمفترسات المصاحبة لها

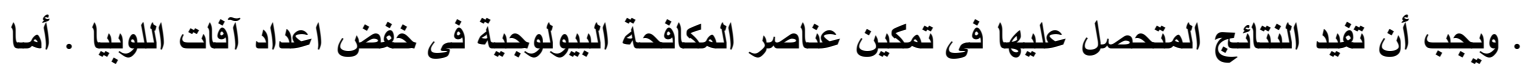

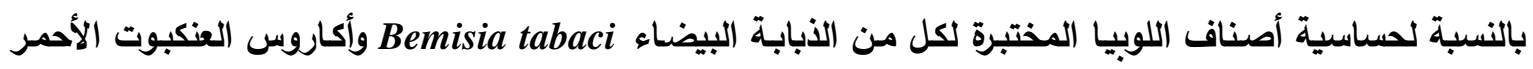
Tetranychus urticae

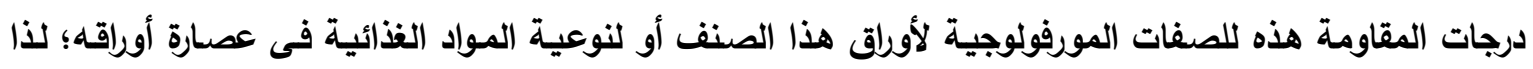
يجب على مربى النباتات دراسة صفات هذا الصنف من اللوبيا بالتفصيل ونقل المرغوب منها إلى أصناف اللوبيا التى يتم إنتاجها حديثاً . 